\title{
Higher Education's Marketization Impact on EFL Instructor Moral Stress, Identity, and Agency
}

\author{
Timothy Scott ${ }^{1}$ \\ ${ }^{1}$ Graduate School of Human Science, Assumption University, Bangkok, Thailand \\ Correspondence: Timothy Scott, School of Human Science, Assumption University, Bangkok, Thailand.
}

Received: November 26, 2020

Accepted: December 22, 2020 Online Published: December 25, 2020

doi: $10.5539 /$ elt.v14n1p99

URL: https://doi.org/10.5539/elt.v14n1p99

\begin{abstract}
Higher educational institutions (HEIs) have experienced a dramatic reconceptualization as academia strives to align its organizational design and civic mission with the societal notion that education is obliged to prioritize quantifiable results. The traditionalistic ethos that knowledge is acquired through reason and the pursuit of critical inquiry has been supplanted by a marketized ideology that education is a transactional process. The latter notion fails to foster the development of students' core competencies. The resulting commodification of education has repurposed HEIs from serving a public good to serving a private good and has impacted institutional policies, program offerings, curriculum design, pedagogy, and instructor and student assessment. English foreign language (EFL) programs face immense pressure to conform to external idealized beliefs concerning appropriate course design and implementation. Such pressure limits instructors' ability to perform their tasks efficiently. The burden of cultural and institutional constraints and unmanageable expectations has led to myriads of professional and moral stresses that negatively affect EFL instructors' identity and agency in their occupation. This article explores the marketization of universities and its subsequent impact on EFL instructors. Demands from various stakeholders create moral stress for instructors; influence instructor identity through shaping the perceived, actual, and external ought self; and produce damaging consequences related to diminished instructor agency in the classroom.
\end{abstract}

Keywords: English foreign language, instructor agency, instructor identity, marketization, moral stress

\section{Introduction}

The commodification of higher educational institution (HEI) programs presents wide-ranging implications that upend traditional processes of education and reconstruct the interrelationships between educators and students. Traditionally, the role of instructors has been to disseminate knowledge, which encompasses providing students with the tools for critical analysis, directing exploration of problem-solving methods, and teaching the skills for constructively expressing views. However, marketization has caused the educator-student relationship to morph into a commercial transaction that bears only a fractional resemblance to traditional education (Noble, 2011). As HEIs have corporatized their paradigms and promoted themselves as idealized brands, the educational experience that they offer has been transformed into a product; instructors, into producers; and students, into customers. By conflating students with customers, HEIs must now prioritize students' desires over their educational needs. Schwartzman (2013) argued that commodification equals "convenience." Rather than espousing attributes that equip students for life's complexities, HEIs seek to satisfy students' desires as paying customers. Advocacy for a market-driven educational approach indicates the impact of how prospective students now evaluate institutions. Rather than students' evaluating an HEI as a foundation of knowledge, they evaluate it through a cost-benefit analysis based on their potential increase in earnings versus the cost of a degree.

Students view themselves as customers paying for a product, they feel more empowered to dictate the conditions of their educational experience. Student empowerment would ideally endow students with active participation in the learning process, which would ideally enable their attainment of knowledge in areas that pertain to the ever-changing global market. However, most students seek the comfort of learning current knowledge over the challenges of intellectual rigor. Arum and Roska (2011) have identified a minimalistic approach to education among students: expending the least amount of effort in accomplishing primary goals. Their study concluded that this "minimax" approach represented the significant cause for the inability of $36 \%$ of all undergraduates to formulate complex arguments and integrate new knowledge into their academic writing (Arum \& Roksa, 2011). 
If market-theory dictates the HEI business model, then instructors will appease the demands of students resistant to intellectual challenge, with negative consequences for academic rigor (Schwartzman, 2013). Because commodification enables students to dictate their educational experience, their perceptions and beliefs gain significant influence on program scope, curriculum design, and instructor choices. Student perception of how classes ought to be designed stems from social constructs that often attribute misinformation or unsubstantiated claims as fact. False perceptions inhibit learning potential, and students reject course designs and curricula that fail to meet their narratives.

English foreign language (EFL) courses, notably those in Asia, face immense pressure from students to adhere to their perceptions of how EFL programs should be designed and who should be teaching them. Asian EFL courses are constrained by a consumer-oriented xenocentric conviction that views foreign native instructors as more qualified solely because they were born in a Western country. Although numerous studies have investigated and disputed most of these perceived claims (Coppieters, 1987; Mahboob, 2004; Medgyes, 1992; Tsou \& Chen, 2017), academic institutions continue to cater to these demands because students do not enroll for instruction from a person who "does not speak English" (Clark \& Paran, 2007). In a drive to satisfy student demands, universities recruit foreign instructors to lead EFL classes and yet subjugate them to a departmental curriculum designed for one size fits all (Ollerhead \& Burns, 2016). Institutional policies further stifle EFL instructors from critically engaging material, limiting their capacity to efficiently conduct classes. EFL instructors are tasked with aligning pedagogical strategies and assessment to local cultural norms and student expectations in stark contradiction to traditional Western ideologies. The accumulation of constraints and expectations imposed on EFL instructors creates a diversity of professional and moral stresses that impact both instructor identity and agency.

This article explores the implications of universities' marketization on foreign language instructors, mainly how demands from various stakeholders create moral stress and influence instructor identity through perceived, actual, and external ought self and the consequence of diminished instructor agency in the classroom. In doing so, the author hopes to recognize issues impacting the EFL classroom to reduce foreign instructors' moral dilemmas through improved identity and enable foreign instructors to become agents of change.

\section{Moral Stress}

Moral stress is defined as a problematic issue that requires action; yet, an array of comparable practical choices exist, each with different consequences. Akbari and Tajik (2019) noted that moral stress is inherent in the EFL profession because instructors engage with numerous stakeholders, each with expectations of prescribed practices that often conflict. Constrained by demands, instructors may not be able to conduct themselves consistently with their morals. Although moral stress is subjective and the choices regarding how to address it may be identified, evaluated, and valued differently, none can be fully rectified. A moral residue results (Cushman \& Young, 2009) that potentially integrates into one's personal views of self. Instructors must endure the unwanted consequences of their choices long after a course of action has been taken. These consequences magnify the complexity of situations where adverse outcomes may become solidified in the daily relations with students, colleagues, or the institution.

As education is an interpersonal profession, all instructors face several moral stresses. However, the overarching role that xenocentric consumers play on foreign EFL instructor recruitment means that unique conflicts arise in the EFL classroom that are not prevalent in other programs. To appeal to students, universities seek to attract enrollment by commodifying foreign EFL teachers and packaging them as a superior option in student language development. This approach creates a dramatic market shortfall for qualified, skilled foreign EFL instructors, especially in the Asian market. Universities recruit teachers who are less experienced and less qualified to fill the void. Institutions attempt to mitigate foreign EFL instructors' relative inexperience by assigning them to basic communication classes with a predesigned set of pedagogical strategies for instruction. Prepackaged methodologies and curriculum set by administrators impede experienced instructors from altering course topics or pedagogical approaches that serve a particular class need. Campbell (1997) explained that forcing instructors to conduct and implement class policies that they oppose results in moral stress that can impact their professional performance and motivation. The conflict between promoting a quality academic experience and balancing policy and resource constraints inflicts anxiety, inhibition, and self-depreciation (Vértiz-Osores et al., 2019).

EFL instructors are confronted with the dilemma of either developing new material and teaching strategies to meet student needs or conforming to their institution's existing policies and course design. Either choice is rife with negative consequences and both short- and long-term ramifications. If instructors alter the prescribed course design, they could face departmental ostracism and professional reprimands. Their employment contract may not 
be renewed or may even be immediately terminated. In most Asian countries, foreign instructors' contracts are terminated and corresponding working visas are canceled, and they must leave the country immediately. If the instructors elect to maintain the predetermined course design, the lessons may be harmful to student success. Students' skill level may not improve or may deteriorate, resulting in declining classroom engagement and lower student performance on assignments and tests. If students perform negatively in national exams, their EFL instructors may be held accountable by the university, and they will likely face disciplinary action for failing to meet the students' needs. The moral paradox of satisfying students' needs over professional security is exacerbated if EFL instructors have settled in the country in which they are teaching and they have personal or family obligations outside the classroom. EFL instructors experience distress caused by compromising their moral values, which erodes their personal and professional integrity and moral agency and potentially leads to resentment, loss of self-worth, risk-avoidance, or a feeling of powerlessness (Ruston et al., 2016).

Student satisfaction assessments serve as an additional cause of EFL instructors' moral stress. The EFL instructor and student interrelationship has morphed into a producer-customer sales cycle model, with teacher performance directly conforming to students' expectations regarding "quality" teaching. The marketization of education dictates that the student (as the customer) acts as the principal agent in the determination of quality instruction. However, the subjectiveness of the term quality results in conflating its meaning with student satisfaction. HEIs rarely define quality in an EFL classroom. Thus, students wield undue influence in its definition through their perceptions and expectations. EFL instructor and student objectives may not align, thus creating a potential conflict. Instructors seeking to satisfy student expectations find their ability to educate content over substance adversely influenced. As Weber (2012) explained, it may be better to "dissatisfy" students by challenging their expectations so they can examine and reflect more critically. Students want to be passively entertained with general topics that do not require extensive language competence. However, instructors who demand rigor, student engagement, and individual ownership for linguistic growth are potentially rewarded with less-than-desirable reviews at the end of the program.

The marketization of education has altered the fundamental objectives of HEIs from imparting knowledge to the retention of students. Recruitment of new students taxes HEIs' finances, retaining students after matriculation improves HEIs' educational return on investment (Dhaqane \& Afrah, 2016). Educational models and course designs incorporate topics and pedagogical strategies that have been previously defined as "quality" by students through student satisfaction assessments. Once ascertained, HEIs create standardized operation procedures (SOPs) with fixed class designs so that EFL instructors will reliably replicate a product that students want. Service quality becomes a by-product of student satisfaction, and HEIs strive for consistency through standardization to build long-term loyalty and reputation (Har et al., 2018). However, EFL learning environment complexities require instructor flexibility to customize curriculum and language presentation toward meeting a sizeable mixed-level classroom's needs, making it impractical to follow a standardized curriculum. Student satisfaction assessments act as a mechanism to ensure instructor compliance to institutional SOPs that strive to satisfy student desires, rather than needs, to assure financial security over intellectual rigor. Weber (2012) argued that educators should not pander to every self-interested student desire but rather should improve students' capacity for making informed judgments through critical thinking. This dichotomy is the foundation of EFL instructors' moral stress: to dissatisfy students to enhance their linguistic competence and risk the wrath of negative reviews or to conform to prescribed HEI conventions and adversely impact the instructor's identity.

\section{EFL Instructor Identity Conflicts}

Instructor identity is a multifaceted concept influenced by instructors' experiences, culture, interpersonal relationships with colleagues and students, workplace demands, and individual moral reasoning. Instructor identity may be summarized as how instructors perceive and visualize themselves (Ottensen, 2007). However, conflicts among influencing agents can lead to a schism between an instructor's professional ideal self, actual self, and external ought self. A professional interpretation of the ideal self includes what attributes, skills, behaviors, and actions instructors aspire to achieve to fulfill their professional goals and responsibilities. Their ideal self indicates how they would answer the question "What type of instructor do I want to be?" Higgins (1987) defined actual self as the attributes, skills, abilities, and behaviors that an individual currently possesses. Self-perception is a critical element that informs one's actual self because an instructor may conflate (or deflate) his or her current attributes and misrepresent his or her objective standing.

EFL instructors' formation of idealized self stems from their experiences and model exemplifiers (their previous instructors) representing a traditional western-education context. EFL instructors may aspire to create an inclusive, student-centric environment that emphasizes communication and collaboration to create professional linguistic competency. To achieve this goal, instructors must possess the skills needed to form a positive learning 
environment through a balance of control and student freedom. The ability of an EFL instructor to identify and offer corrective measures to student learning issues represents the core attribute that instructors strive to achieve. To accomplish this, EFL instructors must be flexible with their lesson delivery and engage in conversations and practices that require modification of the assigned textbook or material. Instructors who realize their ideal self often increase engagement and satisfaction in their workplace conditions, which in turn improves their students' learning environment (Ostad et al., 2019). EFL instructors face the complexities of culture and other external forces that impact development and functioning, creating a discrepancy between their professional actual self and potential for realizing their professional ideal self. Perceived internal and external barriers to actualizing an ideal self can have a psychological impact-evoking dejection or anger-that dramatically influences performance and commitment (Davidi \& Gilovich, 2018). Asian HEI classrooms are rooted in students' ideological beliefs of passive engagement, while the authoritative educator (expert) delivers knowledge to be memorized. Discussion and critical thinking are marginalized in such authoritative classrooms, which favor rote learning and silent obedience (Sit, 2013). EFL communication classes depart from traditional Asian educational tropes of simple memorization in favor of open discussion, a requirement largely nonexistent in students' other courses and likely problematic for many. Cultural norms and HEI policies dictate classroom expectations that counter EFL instructors' ideal self. The result leads to a focal point of resentment or anger, which creates a progressively toxic environment. Instructors with long-term ambitions may internalize these emotions, degrading their motivation to expand their capacity or professional engagement and reducing classroom capabilities.

Additionally, conflict in EFL identity can crystalize through divergence between the instructor's actual self and ought self, dictated by what the HEI or students believe the instructor should attain. This identity discrepancy is compounded by the marketization of education and students' empowerment as customers. Institutional policies may obligate EFL instructors to teach a set curriculum that panders to students' desires over their needs. Thus, the instructor's identity becomes directly correlated to following guidelines and satisfying students' wants. The consumer-oriented xenocentric demands for a foreign EFL instructor integrate physical appearance into required identity. The English language is considered in such contexts as limited to either American or British English, with other varieties of English either marginalized or disregarded as inferior (Mizuta, 2009; Thongcharoen, 2017). Kiczkowiak (2020) referred to the perception of U.S. and U.K. English as linguistically superior as "native speakerism." The paradox of xenocentric demands driving such a racist or xenophobic institutional hiring practice is confounding for instructors who do not fit the desired image (or accent) of an EFL instructor. HEI evaluation of instructors devolves from an educational focus toward evaluation as a pure commodity, in which instructors are rewarded for following a set curriculum and "looking Western." Instructors who offer alternative approaches to topics, institute non-textbook-focused discussions aimed at meeting students' needs, or do not speak with an American or British accent may be punished for their deviations.

HEIs actively discourage critical thinking and flexible pedagogical practice in the classroom (Weber, 2009). Such positive aspects of teaching practice conflict with the EFL instructor identity prioritized by HEIs as optimal. Student expectations for how an instructor ought to lead a class significantly impact the conflict of identities that EFL instructors experience. The student-as-customer wants to be satisfied, unchallenged, and passively engaged in entertaining and uncomplicated classroom discussion. Instructors who are motivated to improve their students' capabilities may "nag" students into participating in a debate that contravenes the student-created parameters of acceptable classroom practice. The student-as-customer may revolt and punish the instructor for creating discomfort because in marketized instruction anything that generates discomfort is attacked, discarded, and replaced with something more pleasing (Baurman, 2007). The students' desire to be pleased, entertained, and safe inside their comfort zone informs their idealization of an EFL instructor identity that is comforting and fun (i.e., an "edutainer").

EFL instructors who strive to educate become vulnerable to fear because their identities defy the assigned identity conceived by the HEI and the students. Higgins (1987) explained that the violating of prescribed teacher duties can impact classroom discipline, requiring situational awareness of adverse outcomes. Fear of punishment and resentment associated with the discrepancy between a teacher's actual identity and conceptual ought identities created by external agents (HEI and students) impact instructor agency. Instructors struggling to align their identities can be emotionally overwhelmed and stressed as they seek to please agents requiring action counter to the instructors' moral beliefs. Peters (1970) captured this conflict with the simplistic reflection that "not all teaching serves to educate." Thus, good teaching represents only the concepts of those evaluating, not the instructor intending to educate. Conforming to expectations at the cost of personal moral judgment creates cyclical identity concerns, reaffirming a more significant disparity between each identity of the instructor and increasing each subsequent conflict's psychological and emotional impact. The abandonment of individual 
conceptions of EFL instructors' identity and acceptance of an identity commanded by external agents deteriorates instructors' choices in the classroom. Consequently, meaningful support to student linguistic development decreases as well.

\section{The De-Professionalization of EFL Instructor Agency}

Instructor agency is the devotion to promoting students' growth through encouragement and the creation of appropriate learning goals. Agency is not a passive response to necessary action (Calvert, 2016), but rather an instructor's awareness of student needs and drive to act. Instructor agency applies to a personal need for professional growth through reflection, professional development, or the pursuit to enact change in the classroom. Agency is not defined by the ability or capacity to act but rather the function of doing or performing an action. The ability to act is regulated by personal motivation; character traits; and environmental conditions, such as school regulations and student desires. The marketization of education and the further commodification of EFL programs have devalued the importance of instructor agency through demanding compliance to set curricula and policies. EFL instructors' experience and judgment regarding student needs have been replaced by an institutionally designed data-generated curriculum (Biesta et al., 2015) that strives to satisfy student wants.

The marketization of education is characterized by the implementation of policies to ensure accountability and compliance. Distrust by HEI administrators of EFL instructors' educational capacities, formed by the lack of qualified foreign instructors, serves as justification for scripted curriculum and oppressive evaluations. Evaluations function as a method for exerting power and control: If an instructor acts in the students' best interests, he or she may therefore be acting against the HEI's best interests. The revoking of EFL instructors' ability to make decisions about what and how they teach subjugates them to the status of a spokesperson rather than that of an educator. The power imbalance faced by EFL instructors also represents HEIs' long-term commitment for the instructor-institution relationship. Unable to participate in course design, collaboration, and student strategy development, EFL instructors' value is not associated with their skills, experience, motivation, or teaching abilities but rather with the degree to which they can act the role assigned to them by the school and desired by the students.

Marketization's empowerment of students as agents of change significantly affects the EFL classroom as well as instructor agency. The balance of instructors' and students' power in the classroom shifts toward students' increased decision-making but does not result in true egalitarianism. Students may resist the HEI-designed curriculum if it challenges them or requires their active engagement. Their resistance to said curriculum is directly correlated with their exerting power over class discourse (Wiseman, 2012), which diminishes EFL instructors' authoritative identity. If EFL instructors lack the authoritative capacity to push hesitant students out of their comfort zone and engage them in topics of relevance, language production and engagement will decline throughout the program. EFL instructors find themselves limited in their ability to reposition themselves and develop a more substantial power balance because they cannot reprimand inactive students nor modify topics to generate renewed interest. The instructors are further limited regarding assessment because institutional policies may forbid the failing of students or the offering of critical feedback. Thus, failure indicates the instructors' inability to follow the prescribed methods. Lack of instructor authority over curriculum, student assessment, and class engagement will often result in instructors merely going through the motions without emotional attachment to their work (Ostad et al., 2016). Students proceed through the program without learning, and instructors perform their job without educating. Void of meaning, EFL instructors lose purpose and personal value, which often results in their cynicism or negative emotional responses about the HEI, students, and the entire education system.

\section{Conclusion}

The effect of the marketization of education has profoundly affected the core tenets of the HEI paradigm, shifting it from promotion of critical inquiry and analysis to acting as a service industry that seeks to please student desires. EFL programs have faced enormous pressure from their target "customers" to adapt course design to incorporate a xenocentric hiring strategy whose goal is not to assist with their students' linguistic development but rather to encourage enrollment through commodifying foreign teachers as a product. Because student interest favors passive engagement with familiar topics, institutions do not encourage EFL instructors to utilize a flexible methodology to target areas of need. Instead, HEIs reward instructors who follow a set of data-driven curricula designed to maximize student satisfaction. Students' assessments of instructors function to punish and hold accountable those EFL instructors who generate dissatisfaction and deviate from the imposed class plan. The power imbalance between the institution and the EFL instructor significantly impairs the 
instructor's ability to act as an agent of change within the classroom. Students' rejection of change or topics that present challenges can further reduce the instructor's classroom agency and thus diminish the potential for overall student improvement. Instructors' consistent emotional stress that results from the failure to achieve their ideal professional self exhibits itself as anger, resentment, or a feeling of worthlessness. Because HEIs have no financial responsibility beyond the classroom instruction, teacher turnover remains high, which in turn justifies the HEIs' rationale for maintaining complete control over EFL instruction. Although the HEIs are satisfied with student enrollment and students are happy with passive engagement, the benefits to all parties (HEIs, students, and foreign EFL instructors) are actually diminished.

It would be naive to expect a seismic shift in HEI practice away from the current market-oriented model in favor of an earlier model of intellectual rigor. Pressure from stakeholders demands a continued focus on satisfying the student-customer's needs through commodifying courses and instructors. The appropriate question that needs to be addressed is how an HEI can follow this current model and reimpose critical thinking and increased instructor agency to reaffirm the importance of qualified foreign EFL instructors as a complement to domestic EFL instructors. HEIs should provide adequate training, support, and mentoring for inexperienced instructors and invest in professional development to best serve student needs. Institutions can continue to provide standardized guidelines and models for classroom curriculum. However, allowing the instructor flexibility to alter content would increase instructor agency and professional identity. Empowered EFL instructors would strive to meet the requirements and obligations set by students and the HEI if both of them are allowed their own beliefs (Yazan, 2018). Including foreign EFL instructors in course development meetings can further instructor engagement because they are part of the process and have a vested interest in its success.

The HEIs and students' assessment and evaluation certainly play a valuable role in instructor development, but assessment criteria and descriptions need to be precise. Questionnaires provided to students can determine whether the course objectives were met, instead of examining whether the student is satisfied with the outcome. HEIs need to consider what the students expect from the course, how much homework the students feel is sufficient, and the students' language goals. Such an approach can better determine whether the program objectives align with students' expectations. Otherwise, either the objectives could be modified (if they are too ambitious) or instructors could improve their presentation to students on student responsibilities related to the course. Student displeasure with a class should not be dismissed, but neither should it be used as the primary indicator of instructor quality. Departments can review student feedback and monitor instructors to ensure that a course and methodology are serving to develop students' abilities. Foreign EFL teachers are not perfect. Certainly, feedback and training may often be necessary. Open dialogue and reasonable expectations by HEIs can mitigate issues and foster instructors' growth. HEI management needs to be presented with the importance of recognizing and developing talented EFL instructors, rewarding instructor successes, and supporting instructor classroom needs (Webster, 2012). EFL instructors' moral stress will be significantly reduced by a collaborative department that desires its foreign instructors to succeed. The long-term commitment by both EFL instructors and HEIs will build improved instructor agency, create opportunities to attain the instructors' ideal professional self, and form rewarding classroom experiences. However, maintaining a consumer-oriented throwaway mentality toward foreign EFL instructors will only discourage qualified instructors from seeking employment within these regions and intensify current instructor turnover, both of which will damage HEIs' long-term success.

\section{References}

Akhari, R., \& Tajik, L. (2019). Insights into TEFL: moral dilemma patterns in teaching practices. Australian Journal of Teacher Education, 44(12), 1-21. https://doi.org/10.14221/ajte.2019v44n12.1

Arum, R., \& Roksa, J. (2011). Academically adrift: Limited learning on college campuses. Chicago: University Of Chicago Press. https://doi.org/10.7208/chicago/9780226028576.001.0001

Bauman, Z. (2007). Consuming life. London: Polity.

Biesta, G., Priestly, M., \& Robinson, S. (2015). The role of beliefs in teacher agency. Teachers and Teaching, 21(6), 624-640. https://doi.org/10.1080/13540602.2015.1044325

Calvert, L. (2016). Moving from compliance to agency: what teachers need to make professional learning work. Oxford, OH: Learning Forward and NCTAF.

Campbell, E. (1997). Administrators' decisions and teachers' ethical dilemmas: implications for moral agency. Leading \& Managing, 3(4), 245-257. 
Clark, E., \& Paran, A. (2007). The employability of non-native-speaker teachers of EFL: A UK Survey. System, 35(4), 407-430. https://doi.org/10.1016/j.system.2007.05.002

Coppierters, R. (1987). Competence differences between native and near-native speakers. Languages, 63(3), 544-573. https://doi.org/10.2307/415005

Cushman, F., \& Young, L. (2009). The psychology of dilemmas and the philosophy of morality. Ethical Theory and Moral Practice, 12(1), 9-24. https://doi.org/10.1007/s10677-008-9145-3

Davidai, S., \& Gilovich, T. (2018). The ideal road not taken: the self-discrepancies involved in people's most enduring regrets. Emotion, 18(3), 439-452. https://doi.org/10.1037/emo0000326

Dhaqane, M. K., \& Afrah, N. A. (2016). Satisfaction of students and academic performance in Benadir university. Journal of Education and Practice, 7(24), 69-63.

Har, C. O. S., Ramasamy, R., \& Binati, R. W. (2018). The relationship among students' loyalty, commitment and trust in private university, Malaysia. BERJAYA Journal of Scervices \& Management, 9, 31-42.

Higgins, E. T. (1987). Self-discrepancy: a theory relating self and affect. Psychological Review, 94, 319-340. https://doi.org/10.1037/0033-295X.94.3.319

Kiczkowiak, M. (2020). Recruiters' attitudes to hiring 'native' and 'non-native' speaker' teachers: an international survey. The Electronic Journal for English as a Second Language, 24(1), 1-22.

Lawrence, S. J. (2012). Consumer xenocentrism and consumer cosmopolitanism: the development and validation of scales of constructs influencing attitudes towards foreign product consumption. Ann Arbor, MI: Proquest LLC.

Mahboob, A. (2004). Native or nonnative: what do students enrolled in an intensive English program think? In L. Kamhi-Stein (Ed.), Learning and teaching from experience: Perspectives on nonnative English-speaking professionals. Ann Arbor, MI: University of Michigan Press.

Medgyes, P. (1992). Native or non-native: who's worth more? ELT Journal, 46(4), $340-349$. https://doi.org/10.1093/elt/46.4.340

Mizuta, A. (2009). The unchanged images of English in changing Japan: from modernization to globalization. Intercultural Communication Studies, 18(2), 38-53.

Noble, D. (2001). Digital diploma mills: the automation of higher education. New York: Monthly Review Press.

Ostad, S. A., Ghanizadeh, A., \& Ghanizadeh, M. (2019). The dynamism of EFL teachers' professional identity with respect to their teaching commitment and job satisfaction. Cogent Education, 6, 1-16. https://doi.org/10.1080/2331186x.219.1685353

Ottensen, E. (2007). Teachers "in the making": building accounts of teaching. Teaching and Teacher Education, 23(5), 612-623. https://doi.org/10.1016/j.tate.2007.01.011

Peters, R. S. (1970). Ethics and Education (2nd ed.). London: George Allen \& Unwin Ltd.

Rushton, C. H., Caldwell, M., \& Kurtz, M. (2016). Moral distress: a catalyst in building moral resilience. American Journal of Nursing, $\quad$ 116(7), https://doi.org/10.1097/01.NAJ.0000484933.40476.5b

Schwartzman, R. (2013). Consequences of commodifying education. Academic Exchange Quarterly, Fall 2013, 41-46.

Sit, H. H. W. (2013). Characteristics of Chinese students' learning styles. International Proceedings of Economics Development and Research, 62, 36-39. https://doi.org/10.7763/IPEDR.2013.V62.8

Thongcharoen, Y. (2017). Perception of Thai EFL students concerning their teacher's competency and empathy. Language Education and Acquisition Research Network (LEARN) Journal, 10(1), 51-74.

Vértiz-Osores, J. J., Ochoa, G. L. V., Vértiz-Osores, R. I., Damián-Núñez, E., Tasayo, H. C., \& Rodríguez-Fuentes, A. (2019). Teacher discomfort: reflections on the low academic performance of university students. Propósitos y Representaciones [Journal of Educational Psychology], 7(3), 286-298. https://doi.org/10.20511/pyr2019.v7n3.387

Webster, R. S. (2012). Challenging student satisfaction through the education of desires. Australian Journal of Teacher Education, 37(9), 81-92. https://doi.org/10.14221/ajte.2012v37n9.6 
Webster, R. S. (2009). How evidence-based teaching practices are challenged by a Deweyan approach to education. Asia-Pacific Journal of Teacher 215-227. https://doi.org/10.1080/13598660902800525

Wiseman, A. M. (2012). Resistance, engagement, and understanding: a profile of a struggling emergent reader responding to read-aloud in a kindergarten classroom. Reading \& Writing Quarterly, 28(3), 255-278. https://doi.org/10.1080/10573569.2012.676407

Yazan, B. (2018). TESL teacher educators' professional self-development, identity and agency. TESL Canada Journal/Revue TESL du Canada, 35(2), 140-155. https://doi.org/10.18806/tesl.v35i2.1294

\section{Copyrights}

Copyright for this article is retained by the author(s), with first publication rights granted to the journal.

This is an open-access article distributed under the terms and conditions of the Creative Commons Attribution license (http://creativecommons.org/licenses/by/4.0/). 